\title{
An Overview of Breast Cancer Screening Recommendations
}

\author{
Vidya $\mathrm{S}^{1 *}$ and Santosh $\mathrm{S}^{2 *}$ \\ ${ }^{1}$ Consultant Obstetrician and Gynaecologist, Anand General Hospital, India \\ ${ }^{2}$ Consultant Orthopedic Surgeon, Anand General Hospital, Taluka Palghar, India
}

*Corresponding author: Dr. Vidya Sangare \& Dr. Santosh Sangare, Anand General

\section{Mini Review \\ Volume 3 Issue 2}

Received Date: May 06, 2018

Published Date: May 16, 2018

Hospital, Boisar, Tal, India, Tel: 09823525201/ 09823520820; Email: anandhospital888@gmail.com

\section{Abstract}

Breast Cancer is the most common type of cancer in women and the second leading cause of cancer related deaths next to lung cancer. Although men can also get breast cancer, cases of male breast cancer account for less than $0.05 \%$ of all breast cancer diagnosed. If eight women live to the age of 85 , at least one of them will develop breast cancer in her lifetime. Twothirds of women diagnosed with breast cancer are over the age of 50, and the majority of remaining is between age of 39 and 40. Still there lies some confusion when it comes to Breast Cancer screening. So here are some recommendations for breast cancer screening.

Keywords: Breast Cancer; Screening; Carcinomas; Women; Age

\section{Mini Review}

Definitely beneficial, recommended: Mammogram every 2 years for women age 50-74.

Genetic counseling and possible testing for women with evidence of high risk family history which includes:

- Two 1st degree relatives with breast cancer, including age $>50$.

- Three or more 1 st or 2 nd degree relative with breast cancer.

- 1st or 2 nd degree relative with breast and ovarian cancer.

- 1st degree relative with bilateral breast cancer.

- Breast Cancer in a male relative.

Ashkenazi Jewish women with any 1st or 2nd degree relative with breast or ovarian cancer
- Possibly Beneficial, Individualize: Mammogram in women before age 50 .

- Definitely not Beneficial, Not Recommended: Breast self examination at any age. history

Genetic testing for women without high risk family

Uncertain Benefit: Mammogram in women age >age 75, Clinical Breast examination, MRI of the breasts [1-10].

\section{References}

1. U.S. Preventive Services task Force (2002) Screening For Breast Cancer recommendation of rationale. Ann Intern Med 137(5): 344-346.

2. Humphrey LL, Helfand M, Chan BK, Woolf SH (2000) Breast Cancer Screening. Rockville. 
3. Humphrey LL, Helfand M, Chan BK, Woolf SH (2002) Breast cancer screening: a summary of the evidence for the U.S. Preventive Services Task Force. Ann Intern Med 137(5): 347-360.

4. Simpson JF, Wilkinson E J (2004) Malignant Neoplasiao if the Breast: Infiltrating carcinomas. In: Bland KI, Copeland EM (Eds.), 3 $3^{\text {rd }}$ (Edn.), St Louis, Saunders.

5. Swhartz GF (2004) Biology and management of lobular carcinoma in situ of breast. In: Bland KI, Copeland EM (Eds.), $3^{\text {rd }}$ (Edn.), St Louis, Saunders.

6. Page DL, LagoisMD (2004) In situ carcinomas of the breast, ductal carcinoma in situ, pagets disease, lobular carcinoma in situ. In: Bland KI, Copeland EM (Eds.), $3^{\text {rd }}$ (Edn.), St Louis, Saunders.

7. (2004) American Cancer Society, cancer facts and figures.

8. (2008) American Cancer Society Statistics.

9. Ries LAG, Melbert D, Krapcho M, Miller BA, Eric J Feuer, et al. (2006) SEER Cancer Statistics review, 1975-2004.

10. Ries LAG, Harkins D, Krapcho M, Miller BA, Eric J Feuer, et al. (2005) SEER Cancer Statistics review, 1975-2003. Bethesda, MD: National Cancer Institute based on november 2005 SEER data submission, posted to the SEER website 2006. 